\title{
THE CONDITION OF THE HARD TISSUES OF THE TEETH IN CHILDREN WITH ACUTE FORMS OF LEUKEMIA
}

\author{
Lehenchuk O.V. https://orcid.org/0000-0001-6901-3932 \\ Plyska O.N. https://orcid.org/0000-0002-3843-5582 \\ Bogomolets National Medical University, Kyiv, Ukraine \\ oksana101117@gmail.com
}

\begin{abstract}
Relevance. Children with oncohematological pathology have a high level of dental diseases, since the use of high doses of cytostatic drugs leads to damage to the hard tissues of the teeth. In recent years, the number of children with acute leukemia has increased in Ukraine from 2.5 to 4.1 cases per 100,000 children. In recent years, the number of children with acute leukemia has increased in Ukraine from 2.5 to 4.1 cases per 100,000 child population.

Objective: to study the indicators of the intensity of caries of temporary and permanent teeth in children with acute forms of leukemia: lymphoblastic and myeloblastic.

Materials and methods. Clinically examined 98 children aged 2-18 years, with acute forms of leukemia. The examined children were divided into groups: the first group - 61 children with acute lymphoblastic leukemia, and the second - 37 children with acute myeloblastic leukemia. Served as control 63 practically healthy children. The analysis of the structure of the constituent elements of the indicators of the intensity of decay teeth caries (df) in children 2-5 years old and caries of permanent teeth (DMF) in children 6-18 years old was performed. The constituent elements of the cf indicator are " $\mathrm{d}$ " - carious teeth that are subject to treatment, "f" - filled teeth. The constituent elements of the DMF indicator are "D" - carious teeth that are subject to treatment; "f" - filled teeth; "M" - extracted teeth.

Results. When studying the intensity of caries of temporary and permanent teeth in children with acute lymphoblastic leukemia, it was found that in children 2-5 years old, cf is equal to 6.64 affected teeth per child. In this case, the "d" element was $75.30 \%$, compared with the control group of children, where the " $\mathrm{f}$ " element was $45.28 \%$. Element " $\mathrm{f}$ " was $24.6 \%$, and in the control group it was significantly higher and was equal to $54.92 \%$. In children with acute lymphoblastic leukemia 6-18 years old, the CFE is 5.34 teeth. At the same time, the "D" element was $53.13 \%$, and in the control group - $11.06 \%$. Element "f" was $44.24 \%$, in the control group - $85.9 \%$. Element "M" in the main group was equal to $2.63 \%$.

When studying the intensity of caries in temporary and permanent teeth in children with acute myeloid leukemia, it was determined that in children 2-5 years of age, cf is equal to 6.25 affected teeth per child. In this case, the "d" element was $80.64 \%$, in comparison with the control group, where the "d" element was 45.28\%. Element "f" was $19.36 \%$, and in the control group it was significantly higher and equal to $54.92 \%$. In children 6-18 years old, the CFE is 5.53 teeth. At the same time, the element "d" in the main group was $41.5 \%$, and in the control group - $11.06 \%$. Element "f" was equal to $57.8 \%$, in the control group - $85.94 \%$. Element "M" in the main group was equal to $0.6 \%$.

Conclusion. Children with acute forms of leukemia have high rates of caries intensity in temporary and permanent teeth.

Keywords: children, caries, intensity, acute lymphoblastic, myeloblastic leukemia.
\end{abstract}

Relevance. Studies conducted by domestic scientists confirm the high prevalence of major dental diseases among children in Ukraine. This is especially true in children with oncohematological pathology. Among the nosologies included in this group, acute leukemias are one of the common diseases of hematopoietic tissue that occur in childhood. In recent years, the number of children with acute leukemia in Ukraine has increased from 2.5 to 4.1 cases per 100,000 children $[3,7]$. Acute myeloblastic leukemia, which accounts for $15-20 \%$ of all forms of leukemia, most often affects children aged 12-14 years and older. Acute lymphoblastic leukemia in $75 \%$ is diagnosed at the age of 2 to 5 years and at the age of 15 to 18 years. Most often, according to statistics, boys get sick. The use of high doses of cytostatic drugs leads not only to lesions of the oral mucosa, as indicated by numerous studies, but also to the damage to the hard tissues of the teeth $[1 ; 2 ; 4 ; 5 ; 8 ; 9]$.
Objective: to study the intensity of caries of temporary and permanent teeth in children with acute forms of leukemia: lymphoblastic and myeloblastic.

\section{MATERIALS AND METHODS}

The study involved 98 children aged 2 to 18 years with acute forms of leukemia, who were treated in the Department of Pediatric Oncohematology of the Kiev Regional Oncological Dispensary. The examined sick children were divided into groups. The first group -61 children with acute lymphoblastic leukemia, of them from 2 to 5 years old -17 children, from 6 to 18 years old 44 children. The second group -37 children with acute myeloid leukemia, of which from 2 to 5 years old -7 children, from 6 to 18 years old -30 children. The control group consisted of 63 practically healthy children, who, in terms of age and sex, coincided with the main group of the surveyed: of them 12 children aged 2-5 years, 51 children aged 6-18 years. Children of the control group 
did not suffer from chronic diseases and rarely (1-2 times a year) suffered from ARI. They went to the Dental Clinic of the National Medical University for oral hygiene. The analysis of the structure of the constituent elements of indicators of the intensity of caries of deciduous teeth (dp) in children 2-5 years old and permanent teeth (DMF) in children 6-18 years old was performed. The constituent elements of the cf-index are: "d" - carious teeth to be treated; $\langle\mathrm{f}\rangle\rangle-$ filled teeth. The components of the DMF index are; $\langle\langle\mathrm{d}\rangle-$ carious teeth to be treated; $\langle\mathrm{f}\rangle\rangle-$ filled teeth; «M»- extracted teeth.

\section{RESULTS AND DISCUSSION}

When studying the intensity of caries of temporary and permanent teeth in children with acute lymphoblastic leukemia, it was determined that in the group of children from 2 to 5 years of age cf-index was equal to 6.64 affected teeth per child. In the group of children from 6 to 18 years, the intensity of dental caries (DMF) was equal to 5.34 teeth. Analysis of the structure of the components of the intensity of dental caries (df) in children 2-5 years is presented in table 1 .

These tables show that in children from 2 to 5 years with acute lymphoblastic leukemia, the element «c») was $75.30 \%$, compared with the control group of children, where the element «c» was equal to $45.28 \%$. The element «f» was in children from 2 to 5 years $24.6 \%$, and in the control group was much higher and equal to $54.92 \%$.

Analysis of the structure of the constituent elements of the cf-index of temporary teeth shows that in this group of children the element " $d$ " prevails over the element " $\mathrm{f}$ ".
In children 6-18 years of the main group, the element " $\mathrm{C}$ " was equal to $53.13 \%$, and in the control group $11.06 \%$. Element " $\mathrm{f}$ " was $44.24 \%$, in the control group $-85.9 \%$. Element " $\mathrm{M}$ " in the main group was equal to $2.63 \%$ (Table 2).

Thus, in children with acute lymphoblastic leukemia, the intensity of the component " $\mathrm{D}$ " prevails over the component " $F$ ", which indicates a lack of treatment and prevention work among this group of children.

Children aged 2-5 years with acute myeloblastic leukemia were equal to 6.25 affected teeth per child. In children 6-18 years DMF was 5.53 teeth. Thus, the intensity of caries in children with acute myeloblastic leukemia, according to WHO criteria, was high in all age groups.

When studying the clinical course of caries, a decompensated form of acute caries with a significant amount of secondary caries in sealed teeth and a rapid complication of caries, especially in temporary teeth, was more often observed. An atypical placement of carious cavities in temporary teeth in children has been established. They were located not only on the masticatory and proximal surfaces, but also on the humps and cervical areas.

When examining the condition of the teeth in children 2-5 years with acute myeloblastic leukemia, it was found that the element «c» was $80.64 \%$, compared with the compared control group of children, where the element “d” was 45.28\%. The element «f»» was 19.36\%, and in the control group - much higher and equal to $54.92 \%$. That is, in this group of children the element "d" prevails over the element «f» (Table 3).

Table 1

The structure of the constituent elements of the intensity of caries of temporary teeth in children 2-5 years with acute lymphoblastic leukemia

\begin{tabular}{|l|c|c|c|c|c|}
\hline \multicolumn{1}{|c|}{ Group } & df & d & \% & f \\
\hline $\begin{array}{l}\text { Patients with acute lymphoblastic leukemia } \\
(\mathrm{n}=17)\end{array}$ & $6,64 \pm 0,2 *$ & $5,0 \pm 0,11^{* *}$ & 75,30 & $1,64 \pm 0,21$ & 24,6 \\
\hline Healthy $(\mathrm{n}=12)$ & $2,3 \pm 0,4 *$ & $1,0 \pm 0,3 *$ & 45,28 & $1,3 \pm 0,65$ & 54,92 \\
\hline
\end{tabular}

Notes for tables 1 and 3. The difference is significant: ${ }^{*} p<0,01 ; *^{*} p<0,05 ; d f$-the number of affected temporary teeth; «d»-decayed toth; $\langle f\rangle$ - filled teeth.

Table 2

The structure of the constituent elements of the intensity of caries of permanent teeth in children 6-18 years old with acute lymphoblastic leukemia

\begin{tabular}{|l|c|c|c|c|c|c|c|}
\hline \multicolumn{1}{|c|}{ Group } & DMF & D & \% & F & \% & M & \% \\
\hline $\begin{array}{l}\text { Patients with acute } \\
\text { lymphoblastic leukemia } \\
(\mathrm{n}=44)\end{array}$ & $4,95 \pm 0,3$ & $2,63 \pm 0,02 * *$ & 53,13 & $2,19 \pm 0,1 *$ & 44,24 & $0,12 \pm$ & 2,63 \\
\hline Healthy $(\mathrm{n}=51)$ & $2,56 \pm 0,22$ & $0,36 \pm 0,11 *$ & 11,06 & $2,20 \pm 0,22$ & 85,94 & 0 & 0 \\
\hline
\end{tabular}

Notes for tables 2 and 4. The difference is significant: *p $<0,01 ; * * p<0,05 ;$ DMF - the number of affected permanent teeth; «d»decayed toth; «F»-filled teeth; «M»-missing removed teeth. 
The structure of the constituent elements of the intensity of caries of temporary teeth in children 2-5 years with acute myeloblastic leukemia

\begin{tabular}{|l|c|c|c|c|c|}
\hline \multicolumn{1}{|c|}{ Group } & cf & c & \% & f & \% \\
\hline $\begin{array}{l}\text { Patients with acute myeloblastic leukemia } \\
(\mathrm{n}=7)\end{array}$ & $6,25 \pm 0,3 *$ & $5,0 \pm 0,22 * *$ & 80,64 & $1,2 \pm 0,21$ & 19,36 \\
\hline Healthy $(\mathrm{n}=12)$ & $2,3 \pm 0,4 *$ & $1,0 \pm 0,3 *$ & 45,28 & $1,3 \pm 0,65$ & 54,92 \\
\hline
\end{tabular}

Table 4

The structure of the constituent elements of the intensity of caries of permanent teeth in children 6-18 years old with acute myeloblastic leukemia

\begin{tabular}{|l|c|c|c|c|c|c|c|}
\hline \multicolumn{1}{|c|}{ Group } & DMF & D & \% & F & \% & M & \% \\
\hline $\begin{array}{l}\text { Patients with acute myeloblastic } \\
\text { leukemia }(\mathrm{n}=30)\end{array}$ & $5,53 \pm 0,4$ & $2,3 \pm 0,2$ & 41,5 & $3,2 \pm 0,01 * *$ & 57,8 & $0,03 \pm 0,02$ & 0,6 \\
\hline Healthy $(\mathrm{n}=51)$ & $2,56 \pm 0,22$ & $0,36 \pm 0,11 *$ & 11,06 & $2,20 \pm 0,22$ & 85,94 & 0 & 0 \\
\hline
\end{tabular}

According to the generally accepted clonal theory of leukemogenesis, the pathogenesis of the development of acute leukemias is likely to begin in the perinatal period. That is, the time at which the number of leukemic clones reaches the number at which leukemia is clinically manifested, is from one year to ten (average 3.5 years) [6]. This coincides with the intensive bookmarking and mineralization of hard tissues of both temporary and permanent teeth in children. This is an important factor in the formation of caries-favorable enamel in this contingent of children.

Analysis of the structure of the constituent elements of DMF teeth in children 6-18 years shows that the element " $\mathrm{d}$ " in the main group was $41.5 \%$, and in the control group $-11.06 \%$. Element " $\mathrm{f}$ " was $57.8 \%$, in the control group $-85.94 \%$. Element " $M$ " in the main group was equal to $0.6 \%$ (Table 4 ).

Comparative analysis showed that component $\langle\mathrm{E} »$ is significantly higher in children with acute lymphoblastic leukemia, compared with the group of children with acute myeloblastic leukemia $-2.63 \%$ vs. $0.6 \%$ (Tables 2,4 ).

\section{CONCLUSIONS}

At children with acute forms of leukemias high indicators of intensity of caries of temporary and permanent teeth are established.

\section{REFERENCES}

1. Boris S.P., Popruzhenko T.V., Krasko O.V. [Risk factors for the development of chemotherapeutic oral mucositis in children and adolescents associated with the characteristics of the patient's body and the underlying disease]. Modern dentistry. 2016; 4: 66-70. [in Russian] View at: URL: https://cyberleninka.ru/article/n/faktory-riska-razvitiya-himioterapevticheskogo-oralnogo-mukozita-u-detey-i-podrostkov-svyazannye-s-osobennostyami-organizma-patsientov
Elibrary: https://www.elibrary.ru/item. asp?id=27639476

Google Scholar: https://scholar.google.com/ citations? user=AOthSKEAAAAJ\&hl=en

2. Kaskova L.F., Vashchenko I.Yu., Yanko N.V., Karpenko O.O., Korotich N.N. [The prevalence and intensity of caries in children with hodgkin's disease, it was examined at different periods of them manifestation]. Ukrainian Dental Almanac. 2015; 3:42-6. [in Ukrainian] View at: URL: http://elib.umsa.edu.ua/handle/ umsa/2978

Cyberleninka: https://cyberleninka.ru/article/n/ poshirenist-ta-intensivnist-karioznogo-protsesu-v-ditey-hvorih-na-limfogranulematoz-obstezhenih-u-rizni-periodi-perebigu-osnovnoyi

3. Klitinska O.V. [Analysis of manifestations of leukemia in the oral cavity in children and adolescents]. Ukraine. Health of the nation. 2016;4(40):28-31. [in Ukrainian] View at: URL: http://nbuv.gov.ua/UJRN/Uzn_2016_4_6

4. Obukhov Yu.A., Zhukovskaya E.V., Karelin A.F. Radiation caries in patients receiving cancer therapy: a review of the literature and their own clinical observations. Russian Journal of Pediatric Hematology and Oncology. 2018;5(4):40-50. doi: 10.17650/2311-12672018-5-4-40-50. [in Russian]

View at: Publisher Site: https://doi. org/10.17650/2311-1267-2018-5-4-40-50

Cyberleninka: https://cyberleninka.ru/article/n/luchevoy-karies-u-patsientov-poluchayuschih-terapiyu-po-povodu-novoobrazovaniy-obzor-literatury-i-sobstvennye-klinicheskie

5. Popruzhenko T.V. Dental care for children with acute lymphoblastic leukemia in an outpatient setting at the stages of diagnosis, planning antitumor therapy and after its completion. Modern dentistry. 2018; 2: 51-7. [in Russian] View at: Cyberleninka: https://cyberleninka.ru/article/n/stomatologicheskaya-pomosch-detyams-ostrym-limfoblastnym-leykozom-v-ambulatornyh-usloviyah-na-etapah-diagnostiki-zabolevaniya 
Elibrary: https://www.elibrary.ru/item . asp?id=35290279PubMed:

6. Shabalov N.P. Childhood diseases. Vol. 1. 8th edition, 2017. 880 p. [in Russian]

View at: URL: http://kingmed.info/knigi/Pediatria/book_4499/Detskie_bolezni_Tom_1_8-e izdanie-Shabalov_NP-2017-pdf

7. Khotimskaya Yu.V. General characteristics of oral mucosa lesions in children with acute leukemia. Modern dentistry. 2016; 1: 80-3. [in Russian]

View at: URL: http://nbuv.gov.ua/UJRN/ss_2016_1_20 Google Scholar: https://scholar.google.com.ua/ citations? user $=7 \mathrm{hE} 3 \mathrm{SNQAAAAJ} \& \mathrm{hl}=\mathrm{ru}$

8. Bowen J. [et al]. Mucositis Study Group of the Multinational Association of Supportive Care in Cancer / International Society of Oral Oncology (MASCC/ISOO). The pathogenesis of mucositis: updated perspectives and emerging targets. Support Care Cancer. 2019;
27(10): 4023-33. doi: 10.1007/s00520-019-04893-z. View at: Publisher Site Scopus: https://link.springer. com/article/10.1007/s00520-019-04893-z

PubMed: https://pubmed.ncbi.nlm.nih.gov/31286231/

9. Ritwik P., Chrisentery-Singleton T.E. Oral and dental considerations in pediatric cancers. Cancer Metastasis Rev. 2020 Mar 01; 39(1):43-53 doi: 10.1007/ s10555-020-09842-5

View at: Publisher Site Scopus: https://link.springer. com/article/10.1007/s10555-020-09842-5

PubMed: https://pubmed.ncbi.nlm.nih.gov/31989506/ Europe PMC: https://europepmc.org/article/ $\operatorname{med} / 31989506$

\title{
СТАН ТВЕРДИХ ТКАНИН ЗУБІВ У ДІТЕЙ З ГОСТРИМИ ФОРМАМИ ЛЕЙКЕМІЙ
}

\author{
Легенчук О.В., Плиска О.М. \\ Національний медичний університет імені О.О.Богомольия, Київ, Україна \\ oksana101117@gmail.com
}

Актуальність. У дітей з онкогематологічною патологією спостерігається високий рівень стоматологічних захворювань, так як застосування високих доз цитостатичних препаратів призводить до ураження твердих тканин зубів. В останні роки кількість дітей, хворих на гострі форми лейкемій, зросла в Україні від 2,5 до 4,1 випадків на 100000 дитячого населення.

Мета: вивчити показники інтенсивності карієсу тимчасових та постійних зубів у дітей з гострими формами лейкемій: лімфобластною та мієлобластною.

Матеріали та методи. Клінічно обстежено 98 дітей, у віці 2-18 років, 3 гострими формами лейкемій. Обстежені діти були розподілені на групи: перша група - 61 дитина з гострою лімфобластною лейкемією та друга - 37 дітей 3 гострою мієлобластною лейкемією. Контролем слугували 63 практично здорові дитини. Проводили аналіз структури складових елементів показників інтенсивності карієсу тимчасових зубів (кп) у дітей 2-5 років та карієсу постійних зубів (КПВ) у дітей 6-18 років. Складовими елементами показника кп $€$ «К» - каріозні зуби, які підлягають лікуванню, «п» - пломбовані зуби. Складовими елементами показника КПВ є «К» - каріозні зуби, які підлягають лікуванню; «П» - пломбовані зуби; «В» - видалені зуби.

Результати. При вивченні інтенсивності карієсу тимчасових та постійних зубів у дітей з гострою лімфобластною лейкемією встановлено, що у дітей 2-5 років кп дорівнював 6,64 уражених зубів на одну дитину. При цьому елемент «К» складав 75,30 \%, в порівнянні з контрольною групою дітей, де елемент «к» дорівнював 45,28 \%. Елемент «п» складав 24,6\%, а в контрольній групі значно вищий і дорівнював 54,92\%. У дітей з гострою лімфобластною лейкемією 6-18 років КПВ дорівнював 5,34 зубів. При цьому елемент «К» дорівнював 53,13\%, а в контрольній групі - 11,06\%. Елемент «П» складав 44,24 \%, в контрольній групі$85,9 \%$. Елемент «В» у основній групі дорівнював 2,63\%.

При вивченні інтенсивності карієсу тимчасових та постійних зубів у дітей з гострою мієлобластною лейкемією визначено, що у дітей 2-5 років кп дорівнював 6,25 уражених зубів на одну дитину. При цьому елемент «к» складав 80,64 \%, в порінянні 3 контрольною групою, де елемент «к» дорівнював 45,28 \%. Елемент «п» складав 19,36 \%, а в контрольній групі був значно вищий і дорівнював 54,92 \%. У дітей 6-18 років КПВ дорівнював 5,53 зубів. При цьому елемент «К» основної групи становив $41,5 \%$, а в контрольній групі - 11,06 \%. Елемент «П» дорівнюв 57,8 \%, в контрольній групі - 85,94 \%. Елемент «В» у основній групі дорівнював $0,6 \%$.

Висновок. У дітей з гострими формами лейкемій встановлені високі показники інтенсивності карієсу тимчасових і постійних зубів.

Ключові слова: діти, карієс, інтенсивність, гостра лейкемія лімфобластна та мієлобластна. 


\title{
СОСТОЯНИЕ ТВЕРДЫХ ТКАНЕЙ ЗУБОВ У ДЕТЕЙ С ОСТРЫМИ ФОРМАМИ ЛЕЙКЕМИЙ
}

\section{Легенчук О.В. Плиска Е.Н.}

\author{
Наичиональный медицинский университет имени А.А. Богомольи̧а, Киев, Украина
}

oksana101117@gmail.com

Актуальность. У детей с онкогематологической патологией наблюдается высокий уровень стоматологических заболеваний, так как применение высоких доз цитостатических препаратов приводит к поражению твердых тканей зубов. В последние годы количество детей, больных острыми формы лейкемии, выросло в Украине от 2,5 до 4,1 случаев на 100000 детского населения.

Цель: изучить показатели интенсивности кариеса временных и постоянных зубов у детей с острыми формами лейкемии: лимфобластной и миелобластной.

Материалы и методы. Клинически обследовано 98 детей в возрасте 2-18 лет, с острыми формами лейкемии. Обследованные дети были распределены на группы: первая группа - 61 ребенок с острой лимфобластной лейкемией, и вторая - 37 детей с острой миелобластной лейкемией. Контролем служили 63 практически здоровых ребенка. Проводили анализ структуры составляющих элементов показателей интенсивности кариеса временных зубов (кп) у детей 2-5 лет и кариеса постоянных зубов (КПУ) у детей 6-18 лет. Составными элементами показателя кп являются «к»- кариозные зубы, которые подлежат лечению, «П» - пломбированные зубы. Составными элементами показателя КПУ являются «К» - кариозные зубы, которые подлежат лечению; «П» - пломбированные зубы; «У» - удаленые зубы.

Результаты. При изучении интенсивности кариеса временных и постоянных зубов у детей с острой лимфобластной лейкемией установлено, что у детей 2-5 лет кп равен 6,64 пораженных зубов на одного ребенка. При этом элемент «к» составлял 75,30 \%, по сравнению с контрольной группой детей, где элемент «к» равнялся 45,28 \%. Элемент «П» составлял 24,6 \%, а в контрольной группе - значительно выше и равнялся 54,92 \%. У детей с острой лимфобластной лейкемией 6-18 лет КПУ равен 5,34 зубов. При этом элемент «К» равнялся 53,13 \%, а в контрольной группе - 11,06 \%. Элемент «П» составлял 44,24\%, в контрольной группе - 85,9\%. Элемент «У» в основной группе был равен 2,63\%.

При изучении интенсивности кариеса временных и постоянных зубов у детей с острой миелобластной лейкемией определено, что у детей 2-5 лет кп равен 6,25 пораженных зубов на одного ребенка. При этом элемент «к» составлял 80,64 \%, в сравнении с контрольной группой, где элемент «к» равнялся 45,28 \%. Элемент «п» составлял 19,36 \%, а в контрольной группе был значительно выше и равнялся 54,92\%. У детей 6-18 лет КПУ равен 5,53 зубов. При этом элемент «К» основной группы составил 41,5 \%, а в контрольной группе - 11,06\%. Элемент «П» был равен 57,8 \%, в контрольной группе - 85,94 \%. Элемент «У» в основной группе был равен $0,6 \%$.

Вывод. У детей с острыми формами лейкемии установлены высокие показатели интенсивности кариеса временных и постоянных зубов.

Ключевые слова: дети, кариес, интенсивность, острая лейкемия лимфобластная и миелобластная. 